\title{
Chinese Theme Park Technology Intervention and Tourist Identification Research: A Case Study of Liuzhou OCT Visionland
}

\author{
Pingting Sun, Mu Zhang* \\ Shenzhen Tourism College of Jinan University, Shenzhen, China \\ Email: *zhangmu@163.com
}

How to cite this paper: Sun, P.T. and Zhang, M. (2019) Chinese Theme Park Technology Intervention and Tourist Identification Research: A Case Study of Liuzhou OCT Visionland. Journal of Service Science and Management, 12, 293-314. https://doi.org/10.4236/jssm.2019.123020

Received: February 11, 2019

Accepted: March 22, 2019

Published: March 25, 2019

Copyright $\odot 2019$ by author(s) and Scientific Research Publishing Inc. This work is licensed under the Creative Commons Attribution International License (CC BY 4.0).

http://creativecommons.org/licenses/by/4.0/

\begin{abstract}
With the advancement of technology and the development of virtual reality (VR) and artificial intelligence (AI) technologies, the technological intervention of Chinese theme parks has brought more and more novelty stimulant experiences to tourists. However, the recognition of tourists is different. China's Liuzhou OCT Visionland is a typical theme park that combines high-tech VR, AI, and indoor and outdoor recreation projects. Based on the reference of domestic and foreign literatures, this paper starts from the network evaluation, and through word cloud analysis, a total of 22 evaluation indicators affecting the recognition of tourists are identified in 5 dimensions, and this paper uses content analysis and importance satisfaction analysis (IPA) analysis to conduct on-the-spot investigation and statistical analysis of visitors to the OCT Visionland and classify them into advantage zone, improvement zone, opportunity zone and maintenance zone to investigate visitors' identity of technical intervention in theme parks. The study found that tourists pay more attention to the factors involved more technical interventions in the theme park and higher technical content. Project safety, experience feeling, novelty, convenience and online payment fluency are its advantages, the degree of recognition is high and should be maintained; for the convenience of transportation, the rationality of project openness, the effectiveness of information release, the network coverage rate and other factors with low technical intervention are relatively low, and should be focused on construction; taking the opportunity zone as a breakthrough, and avoiding spending too much resources in the maintenance area. Finally, the study summarizes the relationship between Chinese theme park technology intervention and tourist identification, and also provides a reference for the construction and operation of the same type of theme park.
\end{abstract}




\section{Keywords}

Theme Park, Technology Intervention, Tourist Identification

\section{Introduction}

Theme park, as its name suggests, is a comprehensive leisure and entertainment venue that combines landscape, environment, rides, performances and exhibitions based on a common or a series of themes [1]. With the continuous advancement of science and technology, more and more new technologies are involved in theme parks. In recent years, the application of new technologies in the design and innovation of theme parks has fully met the needs of people seeking experience. The application of new technologies such as virtual reality (VR) and artificial intelligence (AI) has brought a strong immersive experience to tourists. The theme park belongs to the experience economy, and its core product for visitors is the experience. In the process, visitors will have different levels of recognition for the theme park based on their own experience and satisfaction.

Tourist identification is a kind of psychological cognition that people receive through participation in tourism activities. In this process, different levels of psychological impressions are formed and are reflected in tourism activities and general life. Tourists' perceived value of the theme park contributes to the formation of a higher sense of identity. During the tour, visitors will have different travel experiences through their knowledge of the projects they are visiting. This kind of tourist's experiences directly affects the recognition of visitors to the theme park. While the theme park technology is involved in giving visitors a novelty stimulant experience, visitors have different opinions on their recognition. Visitor recognition depends on the support of the tourists themselves in the hardware equipment and related services of the tourism companies, as well as the evaluation and feedback of themselves or others after the tour.

At present, China's theme parks still face many problems such as homogenization competition, ticket economy, low revisit rate and serious losses in the development process, which hinders the healthy development of tourism to a certain extent [2]. As the degree of homogenization increases, the way to attract tourists with the characteristics of tourism products has begun to slowly lapse. Visitors are more willing to give positive feedback to destinations with high sense of identity and satisfaction, and form positive post-purchase behaviors. In turn, winning the recognition of tourists has become a new competitive force for the sustainable development of tourism enterprises; at the same time, it also directly affects the travel choices of tourists and the willingness to revisit [3]. Therefore, to explore the identification content and mechanism of tourism-related individuals and groups [4], how to enhance the identification and satisfaction of tourists has become an important issue which is urgent to solve for theme park managers. Through the research on the technology intervention 
of Chinese theme parks and the identification of tourists, this paper cannot only reflect the relationship between technical intervention and tourist identification, but also provide some experience for the development of the same type of theme park.

\section{Literature Review}

\subsection{Theme Park Technology Intervention}

Theme parks are a very important leisure and entertainment industry. Some scholars have explained the positive effects of technology on theme parks from the perspective of technical intervention and application. Technological innovation has a huge impact on tourism, providing visitors with more immersive experiences and improved overall satisfaction [5]. Some scholars have also raised the importance of high technology for theme parks. Using advanced technology, the high-tech products will be integrated into the construction direction of theme parks to enhance the participation and entertainment of tourists [6]. Online advertising has a significant impact on visitor satisfaction, and TV/broadcast advertising has significantly strengthened the link between travel prices and visitor satisfaction [7]. In the theme park, there must be high-tech elements and physical interaction, and the theme park must have the ability to combine modern technology and personal viewing participation [8]. With the continuous advancement of technology, high-tech is a prerequisite for the development of theme parks, and high-tech has a strong influence in the theme park industry [9].

The development of information technology is also driving the development of theme parks. The application of communication technology plays a vital role in the development of tourism [10]. Molz J. G. points out that tourism is intertwined by different kinds of technological factors by investigating how tourists travel through mobile technology [11]. The application of information technology contributes to the competitiveness of tourism destinations and the establishment of competitive advantages [12].

Technical intervention plays a vital role in the development of theme parks and future tourism. Some scholars, from the perspective of virtual reality technology, analyze the application of new technologies in theme parks and the management operations and future development trends of theme parks. The application and significance of virtual reality in the field of tourism is huge, and the application of virtual reality in tourism will continue to increase [5]. With the development of VR technology, virtual reality technology is the inevitable trend of urban tourism management, and it is also the inevitable trend of digital cities and smart tourism [13]. Gao Hongbo summarized the development path of VR in China from the perspective of the status quo, problems and trends of China's virtual reality industry, and can also combine $\mathrm{VR}$ with tourism and other related fields [14]. The integration of virtual reality technology and tourism can better promote the development of tourism. According to the real scenic area, the vir- 
tual scenic spot designed by the computing technology can bring a better experience to the tourists than the traditional scenic spots [15]. The functional quality and experience of virtual reality systems have a significant impact on the virtual experience of visitors [16].

\subsection{Tourist Identification Research}

On the basis of constructing a hypothesis model of tourist satisfaction, local identity and local loyalty, empirical analysis shows that tourists' satisfaction has a significant positive impact on local identity [17]. Early visitor identification studies emphasize the visitor experience. From the point of view of subjective participation in construction, identification is an experience [18], and experience is the core of theme park products [19].

By establishing a graphic display system and a landscape interpretation system for theme parks, visitors can intuitively understand various rides and enhance the value of visitors [20]. With the continuous opening of the global tourism market, more and more technology is involved in theme parks, and the importance of visitor participation and visitor experience is highlighted. The theme park experience is an indispensable part of the visitor's tour, creating a personal relevance between the theme park and the client to increase interest in the theme park experience [21]. Li, Q.Y. pointed out that in the era of experience economy, the mainstream of tourists' experience lies in "moving up" from the perspective of film and television theme parks [22]. He, F.Y. through the study of the Chengdu Giant Panda Breeding Base, believes that the environmental education model based on tourism commentary shifts to a mode of emphasis on tourism interpretation and environmental interpretation, as well as being a key to improving the recognition of environmental education in the base [23]. From a psychological perspective, identification is a psychological process. Tourist identification can be analyzed from three aspects: expressing support for tourism enterprises in attitude and behavior, feeling some similar characteristics with employees of tourism enterprises, and being interested in knowing others' evaluation of tourism enterprises [24]. Wang, Y. M. pointed out that tourists' recognition of the safety identification system of cultural heritage scenic spots is affected by the frequency of tourists' travel and the form of tourism; however, it is not completely affected by demographic characteristics [25]. Tourist satisfaction is related to the recognition of tourists to a certain extent. Some scholars have suggested that the satisfaction of tourists is a Post hoc experience assessment [26]; it is the involvement of technology in the relatively "realistic" immersive or enhanced experience of theme parks to enhance visitor acceptance and satisfaction. $\mathrm{Xu}, \mathrm{Y} . \mathrm{H}$. analyzed the relationship between tourist satisfaction and revisiting willingness in theme parks [27]; if they meet the changing needs of theme park visitors, they will get higher satisfaction and revisiting rate [28].

Throughout the literature at home and abroad, the current research on theme parks at home and abroad mainly focuses on tourists' satisfaction, visitor expe- 
rience, application of new technologies, management mode exploration and tourism image shaping. It seems that more research is being carried out from the perspective of technology and visitor perception; however, research on the technical intervention of theme parks and the identification of tourists is rare. With the advancement of science and technology, high-tech is widely used in theme parks, and the role of technological intervention in the satisfaction and recognition of tourists cannot be ignored. However, the technical intervention of theme parks cannot fundamentally improve the satisfaction and recognition of tourists. Technical intervention is not the only factor that affects the identity of tourists. At the same time, there are some problems of low recognition of tourists in the theme parks that focus on new technologies. Therefore, it is necessary to conduct relevant research on the technical intervention of the theme park and the identification of tourists, and also provide some reference for the same type of theme park.

\section{Theory and Method}

\subsection{Theory Discussion}

\section{1) Technology Acceptance Model}

The Technology Acceptance Model (TAM) was first proposed by an American scholar, Davis, in 1989 [29]. The technology acceptance model is a model proposed by the rational behavior theory to study the user's acceptance of the information system. It was originally an explanation of the decisive factors that were widely accepted by computers. The technology acceptance model proposes two main determinants: 1) perceived usefulness, reflecting the extent to which one considers the use of a specific system to improve his job performance; 2) perceived ease of use, reflecting the extent to which a person thinks it is easy to use a specific system. TAM considers that the actual use of technology is determined by the intention of the action from a cognitive perspective, and the behavioral intention is determined by the user's attitude towards using and perceived usefulness. The attitude of using behavior is determined by the usefulness and ease of use of the perception while the usefulness of perception is determined by the ease of use of perception and external variables. Perceptual ease of use is determined by external variables (Figure 1). Tourist identification is a kind of psychological cognition. Cognition belongs to the category of attitude, and attitude is also related to behavioral intention. Therefore, according to TAM theory,

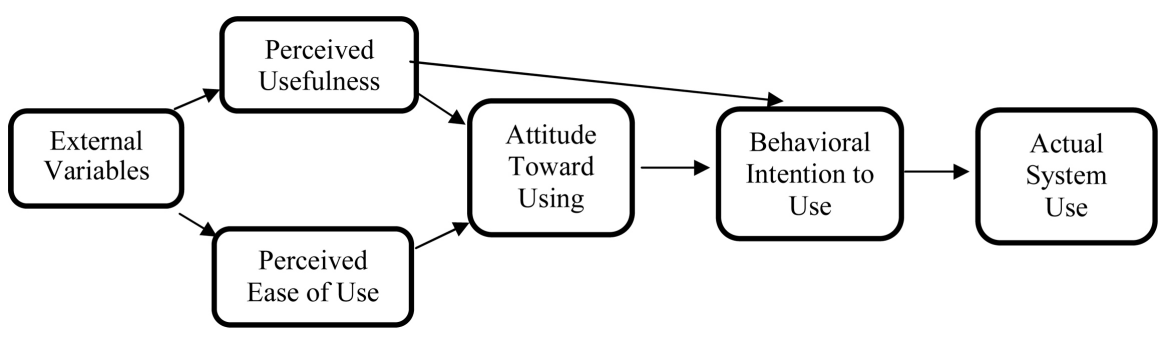

Figure 1. Technology acceptance model. 
there is a correlation between tourist identification, attitude of use and behavioral intention.

2) Attitude Theory

Attitude theory refers to the theory of the formation, transformation and measurement of attitudes. Allport, a famous American social psychologist, pointed out in 1924: "Attitude affects people's cognition and evaluation of society." The theory holds that attitude is a psychological tendency of individuals to a certain kind of social things, including three different dimensions of cognition, emotion and behavior. It has sociality (not inherently), relativity (relative relationship between subject and object), coordination (coordination of understanding, emotion, and behavioral tendency), stability (once formed, it is not easy to change), indirect (behavioral tendency is not the behavior itself). The factors that motivate it include five aspects: need (development in desire satisfaction), group relationship, absorption of new knowledge, personality traits, and imitation.

Tourist perception is a process of psychological cognition obtained by people through sensory information on tourism objects and tourism environmental conditions. It is the process of tourists transforming external tourism information into their own internal thinking. Tourist cognition is the evaluation of tourists' comprehensive environment for tourism destinations. Its particularity is reflected in the blending of tourists' perceptions of objects with people's cognition during the tourism process. Tourist recognition is a kind of psychological cognition that people get by participating in tourism research, tourism activities, and other various matters related to tourism. According to TAM and attitude theory, the relationship between tourist perception and tourist behavior is relatively stable. Visitors' perceptions of the quality of products and services in tourism destinations are related to perception, satisfaction and recognition of value, thereby forming a perceived quality-Perceived value-Tourist satisfaction-a positive chain of tourists' acceptance.

\subsection{Research Process}

In order to construct the theme park technology intervention factors that influence the identification of tourists, based on a large amount of literature, the author draws on the evaluation index of the technical intervention and the identification of tourists in the tourism subject, and further passes through in-depth interviews with the management personnel of the OCT Visionland scenic spot and the practitioners of the scenic spot technology. Based on the results of comprehensive word cloud analysis, a total of 22 evaluation index scales affecting the identification of tourists in five dimensions, including the performance of new technology projects, scenic area intelligent services, project-related settings, auxiliary facilities and post-tourism feedback, were constructed as the core part of the questionnaire.

This study uses content analysis method to analyze the network text; using IPA analysis method to analyze the satisfaction and recognition degree of tour- 
ists in Liuzhou OCT Visionland Scenic Spot. Through field research, questionnaires were used to obtain relevant data, and a confirmatory study was conducted on the evaluation of tourist satisfaction and recognition by constructing four quadrants. Finally, the relationship between theme park technology intervention and tourist identification was obtained. The IPA analysis method was used to study the tourist satisfaction of the OCT Visionland scenic spot. The specific operation steps are as follows: 1) Issue questionnaires for tourists and count the satisfaction and importance of tourists to the various indicators of the OCT Visionland Scenic Area; 2) Using SPSS to calculate the average of the satisfaction and importance of each indicator; 3) Using the total average of the importance of each indicator to find the intersection of the two averages in the IPA diagram, and plotting the four-quadrant of IPA satisfaction and importance (Figure 4); 4) Positioning the indicators one by one in the four-quadrant map, analyzing the advantages and disadvantages, and proposing corresponding countermeasures.

\section{Empirical Analysis: A Case Study of Liuzhou OCT Visionland in China}

\subsection{Case}

Liuzhou OCT Visionland Theme Park is located on the northwest side of Guangxi Gardening and Horticulture Expo, Liudong New District, Liuzhou City, Guangxi Province, China. Liuzhou Dongcheng Investment and Development Group Co., Ltd. is jointly operated by Shenzhen Overseas Chinese Town Cultural Tourism Technology Co., Ltd. under the OCT Group, which has been ranked as the top four global theme park group for 6 consecutive years, with a construction scope of 50 hectares and an investment of nearly 3 billion yuan. A total of 34 indoor and outdoor high-tech experience projects are the largest cultural industry projects in Guangxi and the first Internet theme park in China, which have a strong representation. The park is divided into five major thematic areas, namely, the mermaid kingdom, the Sun tribe, the Carle town, the Cassino street, and the cloud tribe. It includes 15 indoor high-tech projects and 19 outdoor rides, including the world's first film and television jumping machine and the Mirage Theater. The park uses modern technology as the means of implementation, cultural heritage and innovation as the theme content, virtual reality, film and television interaction and other amusement experiences represented by the new cultural park form, cultural content covers modern technology, scientific fantasy, myths and legends, history and culture, theme performance, and so on. Participation and experience are strong, combining culture, art and modern technology perfectly. At the same time, the park applies the hottest VR, AR and other high-tech applications to indoor and outdoor amusement projects, and integrates smart APP technology and Internet IP culture to form a new generation of cultural and technological tourism experience that combines Internet culture, smart scenic spots, and modern science and technology. Based on this, 
this study takes Liuzhou OCT Visionland as the object of empirical research, which has certain representativeness and typicality. Through field research, it analyzes the relationship between Chinese theme park technology intervention and tourist identification, and also provides a reference for the construction and operation of the same type of theme park.

\subsection{Network Text Analysis}

1) Network Sample Selection

Through the comparison of several well-known travel websites in China, it is found that the number of visitors on the Ctrip website is high and the text data are rich enough to meet the research needs of this paper. Therefore, this article has a strong representation through the Ctrip website 401 evaluation as a tourist destination evaluation information. This article comprehensively selected 401 (nearly 24,600 words) articles for the evaluation of OCT Visionland from October 2017 to December 2018.

2) Word Cloud Keyword Analysis

In order to more easily and intuitively reflect the perception of tourists, the selected network evaluations exclude 21 invalid comments such as duplicates and unclear references, and finally, 380 available comments were selected as research samples; using the word cloud generator software for data processing and merging synonyms; for example, culling with terms such as "here" and "just", etc., and finally getting 75 praises and bad comments of high frequency keywords. A word cloud map is generated (see Figure 2 and Figure 3) and high-frequency words are extracted (see Table 2 and Table 3 ). The size of the font size in the figure corresponds to the frequency of occurrence of the vocabulary. The higher the frequency, the larger the font size, and the hot words of the tourists' evaluation can be intuitively seen from the graph.

Nouns, adjectives and verbs are the main high-frequency keywords in the top 75 of tourists' online evaluation (praise) of the OCT Visionland. The number of nouns is the most (52), mainly objective descriptions of scenic spots facilities

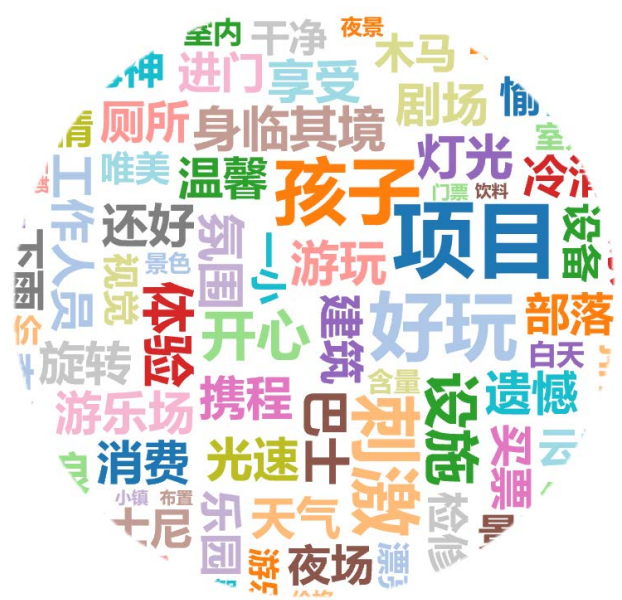

Figure 2. Praise. 


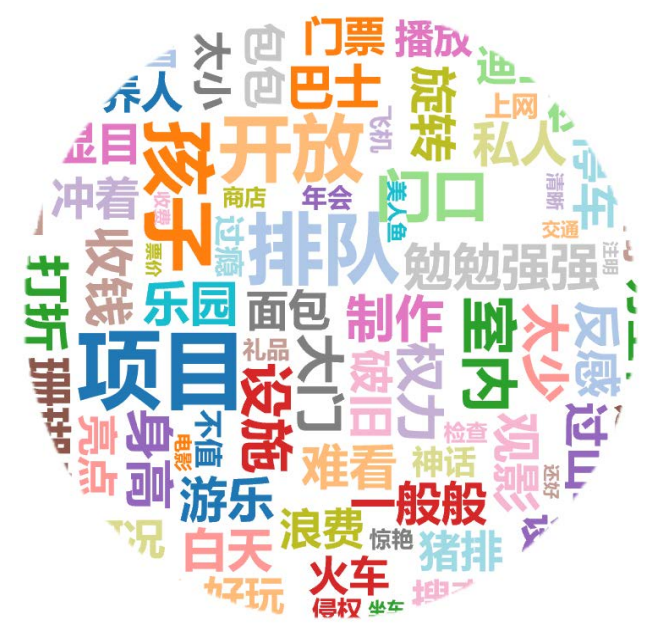

Figure 3. Bad comments.

and services, suitable people, and characteristics of scenic spots; the number of adjectives is second (15), mainly reflecting the sensory and attitude characteristics of tourists; there are 8 verbs, mainly reflecting characteristics of activities such as behaviors, motivations, and processes of tourists during the tour.

It can be seen from Table 1 that in the network evaluation (praise) of the tourists for the OCT Visionland, from the top-ranked high-frequency keywords that are most mentioned, the "project" (3.44) as the main body and core of tourism activities is the most mentioned vocabulary by tourists; from the second ranked "fun" (3.111), the fourth "stimulate" (2.935), the sixth "happy" (2.623) and the ahead ranked "Pretty" (2.173), "open" (2.143), and other adjectives can be seen as the characteristics of the theme park's visionland. The characteristics can reflect the experience and feelings of tourists, and give relative certainty. Judging from the third "child" (3.055), it can be concluded that children are an important part of tourists to the OCT Visionland; from the "facility" that follows (2.683), "surroundings" (2.31), etc. indicate that tourists pay more attention to these aspects and give affirmation to the hardware of the park; Nouns from the top ranked "planet" (2.231), "ferris wheel" (2.173), "park" (2.11), "roller coaster" (1.964), "the film" (1.922), "myth" (1.877) and other projects have successfully attracted the attention of tourists and become a popular and the most mentioned tourist items for visitors; from "experience" (2.521), "play" (2.464), "viewing" (1.596), "photographing" (1.349), etc., the set op-ranking verbs indicate the main purpose of the visitor to the OCT Visionland.

Nouns, adjectives and verbs are the main names of the top 75 high-frequency keywords in the online evaluation (bad review) of the card. The number of nouns is the largest (38), mainly objective descriptions of scenic spots facilities and services, unsuitable people, etc. The number of verbs is second (23), which mainly reflects the characteristics of tourists' behaviors, motivations and experience during the tour. There are 14 adjectives, which mainly reflect the sensory and attitude characteristics of the tourists. 
Table 1. Praise high-frequency characteristic word statistics.

\begin{tabular}{|c|c|c|c|c|c|c|c|c|c|c|c|c|c|c|}
\hline 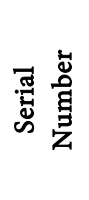 & 矛雚 & 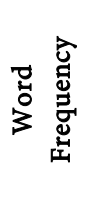 & 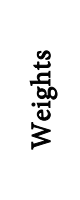 & 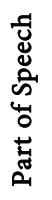 & 㥈 & 苛 & 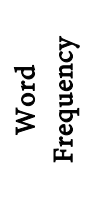 & 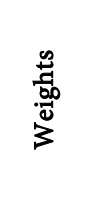 & 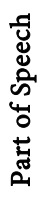 & 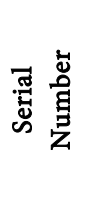 & 氛总 & 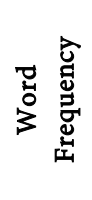 & 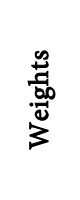 & 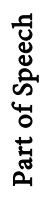 \\
\hline 1 & Project & 142 & 3.44 & $\mathrm{n}$ & 26 & Myth & 14 & 1.877 & $\mathrm{n}$ & 51 & Good & 7 & 1.441 & $\mathrm{a}$ \\
\hline 2 & Fun & 88 & 3.111 & $\mathrm{a}$ & 27 & Liuzhou & 12 & 1.778 & $\mathrm{n}$ & 52 & In The Park & 7 & 1.441 & $\mathrm{n}$ \\
\hline 3 & Child & 81 & 3.055 & $\mathrm{n}$ & 28 & Light & 12 & 1.778 & $\mathrm{n}$ & 53 & Cheap & 7 & 1.441 & $\mathrm{a}$ \\
\hline 4 & Stimulate & 68 & 2.935 & $\mathrm{a}$ & 29 & Price & 11 & 1.722 & $\mathrm{n}$ & 54 & Height & 7 & 1.441 & $\mathrm{n}$ \\
\hline 5 & Facility & 47 & 2.683 & $\mathrm{n}$ & 30 & Disney & 11 & 1.722 & $\mathrm{n}$ & 55 & Program & 7 & 1.441 & $\mathrm{n}$ \\
\hline 6 & Happy & 43 & 2.623 & $\mathrm{a}$ & 31 & Sun & 11 & 1.722 & $\mathrm{n}$ & 56 & Traffic & 7 & 1.441 & $\mathrm{n}$ \\
\hline 7 & Experience & 37 & 2.521 & $\mathrm{v}$ & 32 & Landscape & 11 & 1.722 & $\mathrm{n}$ & 57 & World & 7 & 1.441 & $\mathrm{n}$ \\
\hline 8 & Play & 34 & 2.464 & $\mathrm{v}$ & 33 & Viewing & 9 & 1.596 & $\mathrm{v}$ & 58 & Technology & 7 & 1.441 & $\mathrm{n}$ \\
\hline 9 & Not Lined up & 27 & 2.31 & $\mathrm{v}$ & 34 & Cost-effective & 9 & 1.596 & $\mathrm{a}$ & 59 & Tribe & 6 & 1.349 & $\mathrm{n}$ \\
\hline 10 & Surroundings & 27 & 2.31 & $\mathrm{n}$ & 35 & Small Town & 9 & 1.596 & $\mathrm{n}$ & 60 & Doorway & 6 & 1.349 & $\mathrm{n}$ \\
\hline 11 & Planet & 24 & 2.231 & $\mathrm{n}$ & 36 & Performance & 9 & 1.596 & $\mathrm{n}$ & 61 & Buy Tickets & 6 & 1.349 & $\mathrm{v}$ \\
\hline 12 & Ferris Wheel & 22 & 2.173 & $\mathrm{n}$ & 37 & Device & 9 & 1.596 & $\mathrm{n}$ & 62 & Lively & 6 & 1.349 & a \\
\hline 13 & Pretty & 22 & 2.173 & $\mathrm{a}$ & 38 & High-tech & 8 & 1.523 & $\mathrm{n}$ & 63 & Atmosphere & 6 & 1.349 & $\mathrm{n}$ \\
\hline 14 & Open & 21 & 2.143 & $\mathrm{a}$ & 39 & Atmosphere & 8 & 1.523 & $\mathrm{n}$ & 64 & Good Looking & 6 & 1.349 & $\mathrm{a}$ \\
\hline 15 & Park & 20 & 2.11 & $\mathrm{n}$ & 40 & Vision & 8 & 1.523 & $\mathrm{n}$ & 65 & Complete & 6 & 1.349 & $\mathrm{a}$ \\
\hline 16 & Day & 20 & 2.11 & $\mathrm{n}$ & 41 & Pirate Ship & 7 & 1.441 & $\mathrm{n}$ & 66 & Crazy & 6 & 1.349 & a \\
\hline 17 & Night View & 19 & 2.077 & $\mathrm{n}$ & 42 & Sun God & 7 & 1.441 & $\mathrm{n}$ & 67 & Overall Feeling & 6 & 1.349 & $\mathrm{n}$ \\
\hline 18 & Indoor & 19 & 2.077 & $\mathrm{n}$ & 43 & Tour Park & 7 & 1.441 & $\mathrm{n}$ & 68 & Photographing & 6 & 1.349 & $\mathrm{v}$ \\
\hline 19 & Play & 18 & 2.041 & $\mathrm{v}$ & 44 & Coral Island & 7 & 1.441 & $\mathrm{n}$ & 69 & Wonderful & 6 & 1.349 & $\mathrm{a}$ \\
\hline 20 & Night Field & 16 & 1.964 & $\mathrm{n}$ & 45 & Ctrip & 7 & 1.441 & $\mathrm{n}$ & 70 & The Weather & 6 & 1.349 & $\mathrm{n}$ \\
\hline 21 & Roller Coaster & 16 & 1.964 & $\mathrm{n}$ & 46 & Playground & 7 & 1.441 & $\mathrm{n}$ & 71 & Tall & 6 & 1.349 & a \\
\hline 22 & Park & 16 & 1.964 & $\mathrm{n}$ & 47 & Jump Off & 7 & 1.441 & $\mathrm{v}$ & 72 & Feel & 6 & 1.349 & $\mathrm{n}$ \\
\hline 23 & The Film & 15 & 1.922 & $\mathrm{n}$ & 48 & Christmas Eve & 7 & 1.441 & $\mathrm{n}$ & 73 & Online & 6 & 1.349 & $\mathrm{n}$ \\
\hline 24 & Friend & 14 & 1.877 & $\mathrm{n}$ & 49 & Outdoor & 7 & 1.441 & $\mathrm{n}$ & 74 & $\begin{array}{c}\text { Haunted } \\
\text { House }\end{array}$ & 5 & 1.242 & $\mathrm{n}$ \\
\hline 25 & Ticket & 14 & 1.877 & $\mathrm{n}$ & 50 & Joy & 7 & 1.441 & $\mathrm{a}$ & 75 & Guta & 5 & 1.242 & $\mathrm{n}$ \\
\hline
\end{tabular}

It can be seen from Table 2 that in the network evaluation (bad comments) of the tourists for the OCT Visionland, from the top-ranked high-frequency keywords that are most mentioned, the "project" (2.861) as the main body and core of tourism activities is the most concerned by tourists; from the second ranked "queue" (2.38), the fourth ranked "open" (1.964) and the ahead ranked verbs such as "force" (1.349), "infringement" (1.349), "waste (1.116), "examination" (1.116) and "toll" (1.116) can be seen that tourists' dissatisfaction with the OCT Visionland is mainly concentrated on the poor experience of the tour process and some unreasonable settings; From the eighth ranked "too little" (1.523) and top ranked "not worth" (1.242), "not fun" (1.242) to "crazy" (0.961), "so-so" (0.762), "regret" (0.762), "cheat" (0.762) and other adjectives reflect the poor 
Table 2. Bad evaluation high-frequency characteristic word statistics.

\begin{tabular}{|c|c|c|c|c|c|c|c|c|c|c|c|c|c|c|}
\hline 氶莒 & 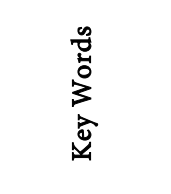 & 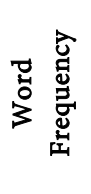 & $\begin{array}{l}\frac{\infty}{4} \\
\frac{0}{00} \\
3\end{array}$ & 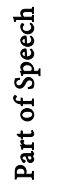 & 氶莒 & 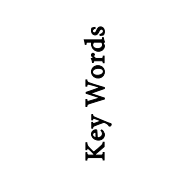 & 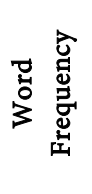 & 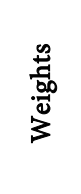 & 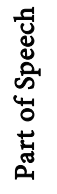 & 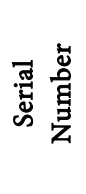 & 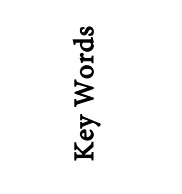 & 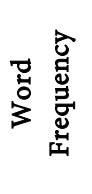 & 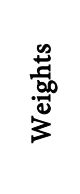 & 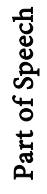 \\
\hline 1 & Project & 61 & 2.861 & $\mathrm{n}$ & 26 & Toll & 4 & 1.116 & $\mathrm{v}$ & 51 & Night Field & 2 & 0.762 & $\mathrm{n}$ \\
\hline 2 & Queue & 30 & 2.38 & $\mathrm{v}$ & 27 & Price & 4 & 1.116 & $\mathrm{n}$ & 52 & Highlight & 2 & 0.762 & $\mathrm{n}$ \\
\hline 3 & Child & 21 & 2.143 & $\mathrm{n}$ & 28 & Halloween & 3 & 0.961 & $\mathrm{n}$ & 53 & Fare & 2 & 0.762 & $\mathrm{n}$ \\
\hline 4 & Open & 16 & 1.964 & $\mathrm{v}$ & 29 & Disney & 3 & 0.961 & $\mathrm{n}$ & 54 & So-so & 2 & 0.762 & $\mathrm{a}$ \\
\hline 5 & Indoor & 11 & 1.722 & $\mathrm{n}$ & 30 & Planet & 3 & 0.961 & $\mathrm{n}$ & 55 & By car & 2 & 0.762 & $\mathrm{v}$ \\
\hline 6 & Doorway & 10 & 1.662 & $\mathrm{n}$ & 31 & Impending & 3 & 0.961 & $\mathrm{v}$ & 56 & $\begin{array}{l}\text { Haunted } \\
\text { House }\end{array}$ & 2 & 0.762 & $\mathrm{n}$ \\
\hline 7 & Facility & 10 & 1.662 & $\mathrm{n}$ & 32 & Height & 3 & 0.961 & $\mathrm{n}$ & 57 & Park & 2 & 0.762 & $\mathrm{n}$ \\
\hline 8 & Too Little & 8 & 1.523 & $\mathrm{a}$ & 33 & Rotate & 3 & 0.961 & $\mathrm{v}$ & 58 & Parking & 2 & 0.762 & $\mathrm{v}$ \\
\hline 9 & Ticket & 8 & 1.523 & $\mathrm{n}$ & 34 & Crazy & 3 & 0.961 & a & 59 & Casual & 2 & 0.762 & $\mathrm{a}$ \\
\hline 10 & Experience & 7 & 1.441 & $\mathrm{v}$ & 35 & The Film & 3 & 0.961 & $\mathrm{n}$ & 60 & Regret & 2 & 0.762 & $\mathrm{a}$ \\
\hline 11 & Food & 7 & 1.441 & $\mathrm{n}$ & 36 & Shut Down & 3 & 0.961 & $\mathrm{v}$ & 61 & Pothole & 2 & 0.762 & $\mathrm{a}$ \\
\hline 12 & Overlord & 6 & 1.349 & $\mathrm{n}$ & 37 & Play & 3 & 0.961 & $\mathrm{v}$ & 62 & Collect Money & 2 & 0.762 & $\mathrm{v}$ \\
\hline 13 & Bread & 6 & 1.349 & $\mathrm{n}$ & 38 & Performance & 3 & 0.961 & $\mathrm{n}$ & 63 & Eat and Drink & 2 & 0.762 & $\mathrm{v}$ \\
\hline 14 & Outdoor & 6 & 1.349 & $\mathrm{n}$ & 39 & Right & 3 & 0.961 & $\mathrm{n}$ & 64 & Bored & 2 & 0.762 & $\mathrm{a}$ \\
\hline 15 & Force & 6 & 1.349 & $\mathrm{v}$ & 40 & Internet Access & 3 & 0.961 & $\mathrm{v}$ & 65 & Vision & 2 & 0.762 & $\mathrm{n}$ \\
\hline 16 & Bag & 6 & 1.349 & $\mathrm{n}$ & 41 & Indicate & 3 & 0.961 & $\mathrm{v}$ & 66 & Too small & 2 & 0.762 & $\mathrm{a}$ \\
\hline 17 & Team & 6 & 1.349 & $\mathrm{n}$ & 42 & Aircraft & 3 & 0.961 & $\mathrm{n}$ & 67 & Ice Sculpture & 2 & 0.762 & $\mathrm{n}$ \\
\hline 18 & Infringement & 6 & 1.349 & $\mathrm{v}$ & 43 & Search & 3 & 0.961 & $\mathrm{v}$ & 68 & Dislike & 2 & 0.762 & $\mathrm{a}$ \\
\hline 19 & Not Worth & 5 & 1.242 & $\mathrm{a}$ & 44 & Traffic & 3 & 0.961 & $\mathrm{n}$ & 69 & Pass & 1 & 0.481 & $\mathrm{n}$ \\
\hline 20 & Not Fun & 5 & 1.242 & $\mathrm{a}$ & 45 & $\begin{array}{c}\text { Entering The } \\
\text { Door }\end{array}$ & 3 & 0.961 & $\mathrm{v}$ & 70 & Closed & 1 & 0.481 & $\mathrm{v}$ \\
\hline 21 & Ferris Wheel & 4 & 1.116 & $\mathrm{n}$ & 46 & Train & 3 & 0.961 & $\mathrm{n}$ & 71 & Viewing & 1 & 0.481 & $\mathrm{v}$ \\
\hline 22 & Roller coaster & 4 & 1.116 & $\mathrm{n}$ & 47 & That power & 3 & 0.961 & $\mathrm{n}$ & 72 & Pit Man & 1 & 0.481 & $\mathrm{a}$ \\
\hline 23 & Waste & 4 & 1.116 & $\mathrm{v}$ & 48 & Private & 3 & 0.961 & $\mathrm{n}$ & 73 & Gloomy & 1 & 0.481 & $\mathrm{a}$ \\
\hline 24 & Clothes & 4 & 1.116 & $\mathrm{n}$ & 49 & Battery Car & 2 & 0.762 & $\mathrm{n}$ & 74 & Explained & 1 & 0.481 & $\mathrm{v}$ \\
\hline 25 & Examination & 4 & 1.116 & $\mathrm{v}$ & 50 & Coral Island & 2 & 0.762 & $\mathrm{n}$ & 75 & Local Breath & 1 & 0.481 & $\mathrm{a}$ \\
\hline
\end{tabular}

experience and feeling of the tourists, which is lower than the expected value, hence giving a negative evaluation.

\subsection{Questionnaire Survey}

The study adopts a questionnaire survey method, which consists of two parts: the first part investigates the importance and satisfaction evaluation of tourists on the service elements of the scenic spot, and uses the Likert 5 subscale method to score, 1 of which is "very important (satisfactory)", 5 is "very unimportant (unsatisfactory)"; the second part investigates the demographic characteristics of tourists, including gender, age, region, education level, occupation, and annual 
household income.

The research data was collected in August 2018 to distribute questionnaires in the field of the OCT Visionland. A total of 424 questionnaires were collected, of which 333 were valid questionnaires and 91 were invalid questionnaires with an effective rate of $78.5 \%$. Descriptive statistical analysis was carried out on the basic information collected in the valid questionnaire. The basic information statistics of the respondents were analyzed by IBM SPSS Statistics 22 software as follows:

Among the 333 valid samples (as shown in Table 3), males accounted for $46.8 \%$ and females accounted for $53.2 \%$; age composition was mainly dominated by young people aged 19 to 28 , accounting for $53.8 \%$ of the sample. From the perspective of the composition of the source of tourists, visitors from Liuzhou, the city where the OCT Visionland is located, accounted for the most (49.6\%), followed by Guangxi province (32.4\%). The investigators were mainly undergraduate and above, with a higher overall education, accounting for $50.2 \%$ of the sample. The surveyed occupations were mostly company employees and students, accounting for $53.8 \%$ and $24.6 \%$, respectively. At the same time, the respondents in the sample had lower incomes, and the highest proportion was an annual income of 30 - 80 thousand yuan (48.6\%), followed by 10 - 30 thousand yuan (27.3\%), and again 80 - 150 thousand yuan (23.5\%).

This study builds an IPA map from the survey data of tourists, analyzes and verifies the difference between importance, satisfaction and quadrant, identifies the relationship between the technical intervention of the theme park and the

Table 3. Demographic characteristics.

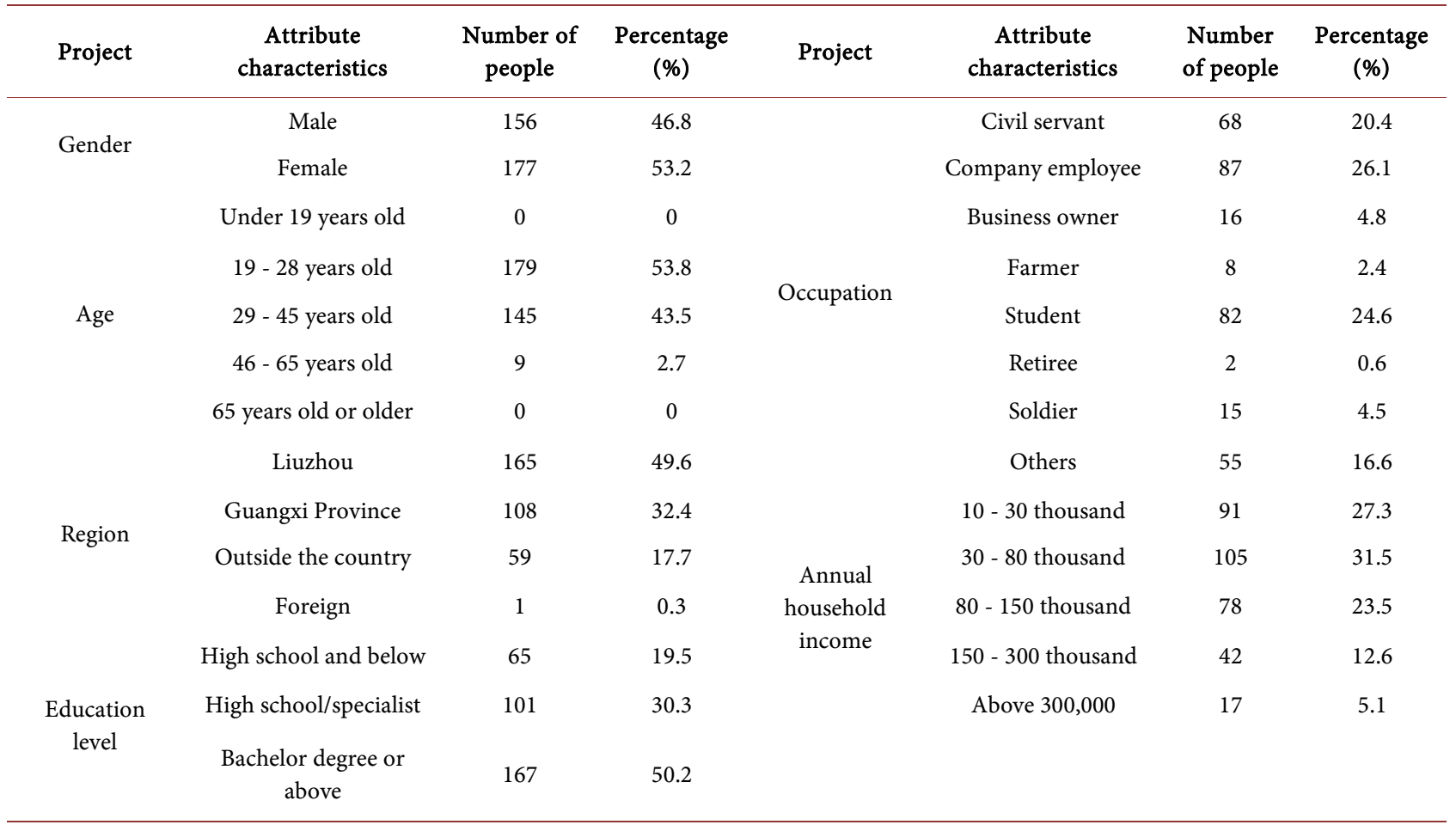


Table 4. IPA analysis results of the OCT Visionland evaluation index.

\begin{tabular}{|c|c|c|c|c|c|c|}
\hline \multirow[b]{2}{*}{ Index } & \multicolumn{3}{|c|}{ Importance } & \multicolumn{3}{|c|}{ Satisfaction } \\
\hline & Mean & Sorting & $\begin{array}{l}\text { Standard } \\
\text { deviation }\end{array}$ & Mean & Sorting & $\begin{array}{l}\text { Standard } \\
\text { deviation }\end{array}$ \\
\hline New technology project security & 4.6877 & 1 & 0.60000 & 3.9850 & 1 & 0.80084 \\
\hline $\begin{array}{l}\text { Scenic video surveillance } \\
\text { full coverage }\end{array}$ & 4.5015 & 2 & 0.66144 & 3.8108 & 4 & 0.78211 \\
\hline $\begin{array}{l}\text { Accuracy and convenience } \\
\text { of the navigation map }\end{array}$ & 4.4775 & 3 & 0.64257 & 3.7778 & 5 & 0.87391 \\
\hline Smart ticket admission speed & 4.4565 & 4 & 0.70416 & 3.7477 & 6 & 0.88972 \\
\hline Online payment system fluency & 4.4384 & 5 & 0.68104 & 3.9610 & 2 & 0.82596 \\
\hline Scenic traffic convenience & 4.4384 & 6 & 0.68983 & 3.5826 & 18 & 0.95214 \\
\hline Project open time rationality & 4.4294 & 7 & 0.63434 & 3.5616 & 20 & 0.94739 \\
\hline New technology project experience & 4.4204 & 8 & 1.72608 & 3.8138 & 3 & 0.87202 \\
\hline Scenic network coverage & 4.3814 & 9 & 0.81137 & 3.6667 & 10 & 0.96630 \\
\hline Novelty of new technology projects & 4.3363 & 10 & 0.69493 & 3.7387 & 7 & 0.82190 \\
\hline $\begin{array}{l}\text { Tourism information is released in } \\
\text { a timely and effective manner }\end{array}$ & 4.2973 & 11 & 0.78304 & 3.5916 & 17 & 0.87202 \\
\hline $\begin{array}{l}\text { New technology projects } \\
\text { can be interactive }\end{array}$ & 4.2883 & 12 & 0.74511 & 3.6096 & 14 & 0.86646 \\
\hline $\begin{array}{l}\text { Mobile client to obtain information } \\
\text { about the scenic spot }\end{array}$ & 4.2733 & 13 & 0.76861 & 3.6066 & 15 & 0.92402 \\
\hline $\begin{array}{l}\text { Humanization of } \\
\text { vehicle parking, etc. }\end{array}$ & 4.2703 & 14 & 0.74784 & 3.5255 & 21 & 0.89009 \\
\hline $\begin{array}{l}\text { Scenic online consultation } \\
\text { complaint suggestion system }\end{array}$ & 4.2162 & 15 & 0.75337 & 3.6006 & 16 & 0.80637 \\
\hline Number of scenic spots & 4.2072 & 16 & 0.74588 & 3.6607 & 11 & 0.85844 \\
\hline Overall evaluation after the tour & 4.0871 & 17 & 0.84396 & 3.6877 & 9 & 0.87385 \\
\hline $\begin{array}{l}\text { Scenic APP use features } \\
\text { and practical convenience }\end{array}$ & 4.0601 & 18 & 0.82286 & 3.5676 & 19 & 0.86729 \\
\hline $\begin{array}{l}\text { Website WeChat scenic area } \\
\text { display and other scenic spots }\end{array}$ & 4.0420 & 19 & 0.80923 & 3.6547 & 12 & 0.82740 \\
\hline $\begin{array}{l}\text { Smartphone and software } \\
\text { recommendation } \\
\text { information richness }\end{array}$ & 4.0390 & 20 & 0.88918 & 3.6456 & 13 & 0.85056 \\
\hline $\begin{array}{l}\text { Short message intelligence } \\
\text { provides travel information }\end{array}$ & 3.9820 & 21 & 0.93443 & 3.5225 & 22 & 0.87309 \\
\hline Recommend this park to others & 3.9580 & 22 & 0.79420 & 3.6997 & 8 & 0.90176 \\
\hline Total mean & 4.2858 & & & 3.6826 & & \\
\hline
\end{tabular}

identification of tourists, and proposes development suggestions, so as to improve the management level of the theme park and provide reference for optimizing the development path.

The study used SPSS22 software to analyze the sample data and obtain the 
score of the overall evaluation index of the sample. In the IPA analysis, the author first used EXCEL to average the 22 importance indicators between 3.9580 and 4.6877, which is considered by OCT Visionland visitors to be more important. The two indicators with the highest average value are "new technology project security" (mean $=4.6877$ ) and "scenic video surveillance full coverage" (mean $=4.5015)$. It can be seen that the importance of travel safety is the first. The third place is "accuracy and convenience of navigation maps" (mean = 4.4775), the fourth place is "smart ticket admission speed" (mean $=4.4565)$ and the fifth place is "online payment system fluency" (mean $=4.4384$ ).It shows that the convenience brought by the new technology to the theme park cannot be ignored, and it is highly valued by tourists. Relatively speaking, "recommend this park to others" (mean $=3.9580)$, "short message intelligence provides travel information" (mean $=3.9820)$ and "smartphone and software recommendation information richness" (mean $=4.0390$ ) are considered the least important indicators. The main purpose of visitors to the OCT Visionland is not to recommend this park to others. Short message and smartphone and software push-related information are also considered unimportant.

The perceived average scores of the 22 satisfaction indicators ranged from 3.5225 to 3.9850. Compared with the importance perception score, the satisfaction score was relatively low, indicating that tourists had higher expectations for the theme park, but the actual situation has been poor. The highest level of satisfaction with tourists is the same as the importance index, for "new technology project security", indicating that not only tourists believe that safety is the most important, but also in the process of experience and play, the safety guarantee is better and the satisfaction is the highest. The second to fourth place is "online payment system fluency" (mean $=3.9610)$, "new technology project experience" (mean $=3.8138)$, and "scenic video surveillance full coverage" (mean $=3.8108)$, indicating that tourists are satisfied with the use of new technologies in payment systems, project experience and scenic area monitoring. The indicators of satisfaction at the bottom are "short message intelligence provides travel information" (mean $=3.5225)$, "humanization of vehicle parking, etc." $($ mean $=3.5255)$ and "project open time rationality" (mean $=3.5616$ ), indicating that there is a big gap between the tourists' expectations for mobile communication, parking problems and project arrangements for the lack of new technology and there are certain problems in the above-mentioned parts.

Based on the calculation results in Table 4, the study included the data in the IPA map, and established a two-dimensional four-quadrant square map by the vertical crossing of the importance mean value of 4.2858 and the satisfaction mean value of 3.6826. The 22 factors (A-U) affecting the theme park were analyzed, and four quadrants were divided according to the location of the mean intersection (Figure 4).

According to the survey results on the importance and satisfaction of the OCT Visionland Theme Park, as shown in Figure 4, we can see that:

The first quadrant is a high importance and high satisfaction area (advanta- 
geous area), including $\mathrm{A}, \mathrm{B}, \mathrm{C}, \mathrm{D}, \mathrm{E}, \mathrm{H}$, and J; that is, new technology project security, scenic video surveillance full coverage, accuracy and convenience of the navigation map, online payment systems fluency, new technology project experience and novelty of new technology projects, have seven influencing factors. In general, tourist recognition reflects better in the above aspects, having obtained higher scores, indicating that they are an important part of the theme park new technology in the park and projects, and at the same time, they have won the approval and satisfaction of tourists. It is the core competitiveness of the OCT Visionland, where managers should strive to keep and maintain these aspects.

The second quadrant is a high-importance and low-satisfaction area (improved area), including F, G, I, K, and L; that is, scenic traffic convenience, project open time rationality, scenic network coverage, tourism information is released in a timely and effective manner, and new technology projects can be interactive. These five factors are very important in the impression of tourists; however, the actual performance of OCT Visionland in these aspects does not meet the needs of tourists. Therefore, we should adopt a key improvement strategy for these five influencing factors, adjust the project opening time to make it more reasonable, improve network coverage, update the release of travel information, and enhance the playability of new technology projects.

The third quadrant is a low-importance and low-satisfaction area (opportunity zone), including factors $\mathrm{M}, \mathrm{N}, \mathrm{O}, \mathrm{P}, \mathrm{R}, \mathrm{S}, \mathrm{T}$, and $\mathrm{U}$; that is, mobile client to obtain information about the scenic spot, humanization of vehicle parking, etc., scenic online consultation complaint suggestion system, number of scenic spots, scenic APP use features and practical convenience, website WeChat Scenic Area Display and other scenic spots, smartphone and software recommendation information richness, and short message intelligence provides travel information offer a total of eight influencing factors. Throughout the IPA analysis, this quadrant has the most factors and is the region with the greatest potential. Although the actual perception of tourists is significantly lower than their expectations,

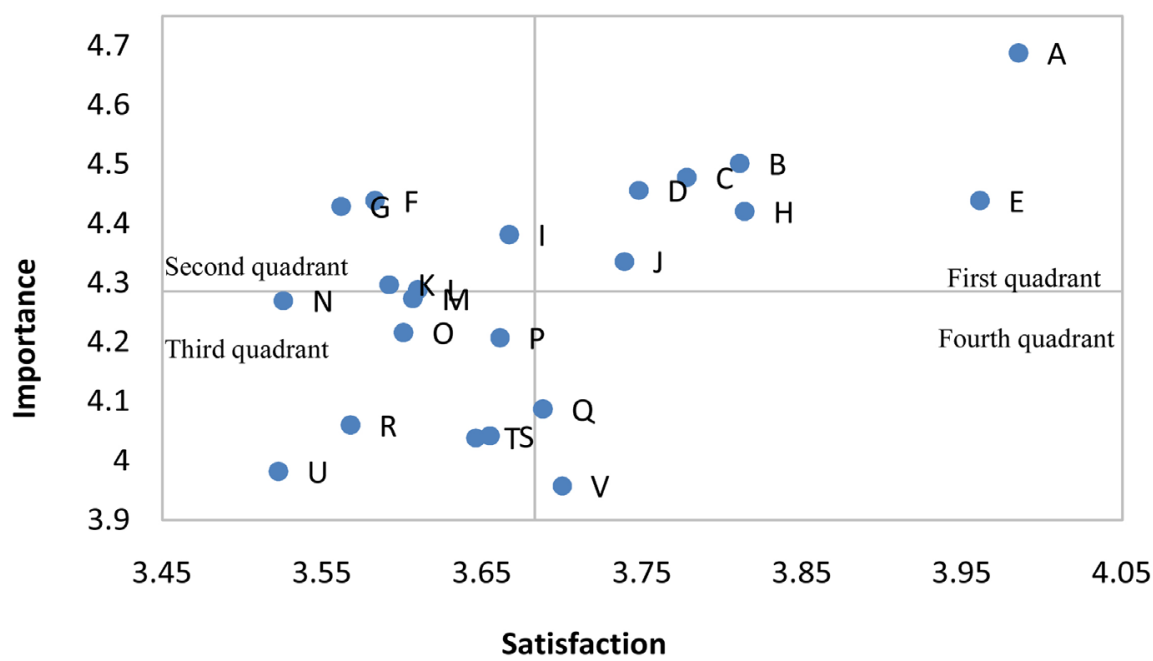

Figure 4. IPA analysis. 
tourists do not value these factors or ignore them to a certain extent. These factors will be transformed into areas that need to be improved depending on the direction of the park, which is also providing a breakthrough for the park managers to enhance the brand characteristics of the OCT Visionland.

The fourth quadrant is a low-importance and high-satisfaction area (maintenance area), including factors $\mathrm{Q}$ and $\mathrm{V}$; that is, an overall evaluation after the tour and recommending the park to others. There are only two factors in this region and they are of low importance. The study found that tourists' satisfaction is high because most tourists do not value it, as maintenance is done on the original basis, and managers do not have to follow up too much.

\section{Conclusion and Recommendation}

\subsection{Conclusion}

Based on the existing research, this paper starts from the network evaluation and uses word cloud software to sort out the keywords to obtain 22 evaluation indicators in 5 dimensions. Through the analysis of relevant indicators, the elements are divided into four quadrants: dominant zone, improvement zone, opportunity zone and maintenance zone, which study the relationship between the technical intervention of Chinese theme parks and the identification of tourists. Through an empirical study of the Liuzhou OCT Visionland, the following conclusions were drawn:

1) The study found that tourists have a high interest in the technical intervention of Chinese theme parks and high technical content, and the recognition is relatively high. In the process of technical intervention, tourists' recognition of the safety of new technology projects far exceeds other factors, and the recognition of the full coverage of scenic spots is also high. It can be seen that the most important role brought about by technological intervention is to enhance the safety and security of theme parks. Due to the great popularity of mobile payment in China today, the recognition of the fluency of online payment systems in theme parks ranks second; the technical intervention of theme parks has greatly promoted the experience and novelty of amusement projects.

2) In contrast, tourists have low recognition of factors such as less technical intervention in Chinese theme parks and relatively low technical content. The scenic traffic convenience, the rationality of the project opening time, the effectiveness of information release and the playability of the project are all less related to the technology. Only improving the technical content cannot be recognized by tourists.

3) In terms of providing tourist with information about theme park (scenic display, SMS, APP and WeChat), theme park supporting services such as online consultation complaints and parking scheduling, etc., have its technical intervention level on average, and the recognition of tourists is relatively lower. This part is not very relevant to technical intervention and the attention of tourists is not high. 


\subsection{Recommendation and Limitation}

In view of the limited research on the technological intervention of Chinese theme parks and the identification of tourists, this study fills the corresponding gap to a certain extent, and it also has certain positive significance and reference for the same type of theme park. The implications of the research findings for the theme park managers are as follows:

First of all, for the industry, the development of science and technology and the tourism industry do not contradict each other, but they complement each other and promote each other. Tourism enterprises should grasp the pulse of the era of technological development and vigorously develop the tourism industry with the advanced technology of the present. At the same time, the development of technology is also inseparable from the tourism industry, with the opportunity of the explosive development of China's tourism industry to promote the development and application of technology in related fields. Tourism enterprises should establish a good image through the intervention and application of new technologies in the tourism industry, increase the perception of tourists on tourism enterprises, enhance their satisfaction, and win the recognition of tourists.

Secondly, theme parks should be based on their own characteristics and future development; they should not blindly pursue capital investment and technological intervention; they should not blindly seek big, new and all in readiness. Also, business strategies should be adjusted according to local conditions, reasonable layout, and local economic, cultural, climatic and geographical conditions to enhance market competitiveness.

Thirdly, it is recommended that the managers of theme parks focus on optimizing management content, rationally diverting to reduce queues, and improving the playability of the project; combining the location of the scenic spot with the actual traffic and scientifically arranging the project opening time to improve the project utilization rate and frequency; publishing relevant information about the park on various media platforms in a timely manner, so that visitors can obtain information conveniently and quickly; relevant technical interventions can be appropriately implemented to enhance management services in the above areas. It is recommended that managers can seize opportunities and improve the theme park supporting services such as providing information channels, online consultation complaints and parking scheduling without increasing the cost of technology, so as to achieve the goal of improving the recognition of tourists.

The study has the following limitations: First, the number of online evaluation samples is limited, and the data is relatively one-sided. Second, in field research, due to the limitations of time, cost and other factors, the questionnaire collection is relatively concentrated. In the future, more research samples should be conducted in a longer period of time to obtain more general analysis conclusions, in order to continuously improve the relationship between technical intervention and the identification of tourists. 


\section{Acknowledgements}

This project was supported by the Shenzhen Social Science Foundation (Grant No. SZ2018B003). The project title is: A study on the cultivation and development of new cultural business forms in Shenzhen.

\section{Conflicts of Interest}

The authors declare no conflicts of interest regarding the publication of this paper.

\section{References}

[1] Zhong, S.E., Zhang, J., Li, L. and Zhong, J. (2015) Review, Evaluation and Prospect of the Development of Chinese Theme Parks. Tourism Journal, 30, 115-126.

[2] Xu, H. and Li, Q.Y. (2016) How Does the Customer Evaluate the Quality of the Experience? Qiuyun Is Based on the Event-Attribute Analysis of Online Reviews. Tourism Science, No. 3, 44-56.

[3] Pan, Z.Q. and Liang, B.E. (2016) Effect of the Validity of Signage on the Local Identity and Loyalty of Tourists: A Case Study of Shanghai Historic District. Tourism Journal, 31, 97-108.

[4] Yu, X.Y., Wu, D.F., Zhu, G.X. and Li, D.M. (2015) Identity Research in the Perspective of Tourism: Based on the Perspective of Literature Review. Human Geography, No. 2, 15-22.

[5] Guttentag, D.A. (2010) Virtual Reality: Applications and Implications for Tourism. Tourism Management, 31, 637-651. https://doi.org/10.1016/j.tourman.2009.07.003

[6] Hao, M.T. and Li, J. (2012) Development of Research on Theme Parks at Home and Abroad. Western Forestry Science, 41, 119-123.

[7] Chiang, M.C., Lin, L. and Hsien, H.C. (2016) Advertising Medium Effect on Tourist Satisfaction. Annals of Tourism Research, 57, 268-272. https://doi.org/10.1016/j.annals.2015.11.016

[8] Jiang, Z. (2017) The Status Quo of China's Theme Parks and Its Future Development Trends: A Case Study of Changzhou Yancheng Chunqiu Paradise. Social Scientist, No. 2, 91-96.

[9] Xu, J. (2018) Development Trend of Typical Global Theme Parks. Competitive Intelligence, 14, 58-63.

[10] Zhang, Y., Cao, J.J., Qi, L. and Wu, B.H. (2013) Research on the Characteristics of Virtual Network Structure of Tourism Destination: A Case Study of Huangshan City. Journal of Peking University (Natural Science Edition), 49, 1098-1104.

[11] Molz, J.G. (2013) Travel Connections: Tourism, Technology, and Togetherness in a Mobile World. Annals of Tourism Research, 40, 442-444. https://doi.org/10.1016/j.annals.2012.11.003

[12] Law, R., Buhalis, D. and Cobanoglu, C. (2014) Progress on Information and Communication Technologies in Hospitality and Tourism. International Journal of Contemporary Hospitality Management, 26, 727-750. https://doi.org/10.1108/IJCHM-08-2013-0367

[13] Wang, H.S. and Zhou, H.Y. (2014) Design and Implementation of Tourism Information System Based on WebGIS and Virtual Reality. Journal of Guilin University of Technology, No. 2, 355-359.

[14] Gao, H.B. (2017) China's Virtual Reality (VR) Industry Development Status, Prob- 
lems and Trends. Modern Media, No. 2, 8-12.

[15] Jiang, M.Y. (2018) Application Research of Virtual Reality Technology in Virtual Scenic Area Design: A Case Study of Cao Caoyunbing Road in Zhangzhou. Journal of Foshan University of Science and Technology (Natural Science Edition), 36, 31-34.

[16] Wei, W., Qia, R.X. and Zhang, L. (2019) Effects of Virtual Reality on Theme Park Visitors' Experience and Behaviors: A Presence Perspective. Tourism Management, 71, 282-293. https://doi.org/10.1016/j.tourman.2018.10.024

[17] Yuksel, A., Yuksel, F. and Billim, Y. (2010) Destination Attachment: Effects on Customer Satisfaction and Cognitive, Affective and Conative Loyalty. Tourism Management, 31, 274-284. https://doi.org/10.1016/j.tourman.2009.03.007

[18] Chen, C. and Lu, C. (2011) Identity: A New Perspective of Tourism Experience Research. Tourism Journal, 26, 37-42.

[19] Li, S.L. (2012) Research on the Experiential Design Pattern of Theme Park: A Case Study of Xi'an Datang Furong Garden. Resource Development and Market, No. 4, 381-384.

[20] Lian, T.H., Yu, C.H., Bao, X.J. and Lu, S. (2012) Research on Tourist Satisfaction of Theme Parks Based on Fuzzy Comprehensive Evaluation: A Case Study of Wuhu Fangte Joy World. Resource Science, 34, 973-980.

[21] Ma, J.Y., Gao, J., Scott, N. and Ding, P.Y. (2013) Customer Delight from Theme Park Experiences: The Antecedents of Delight Based on Cognitive Appraisal Theory. Annals of Tourism Research, 42, 359-381. https://doi.org/10.1016/j.annals.2013.02.018

[22] Li, Q.Y., Huang, Y., Zhou, L.J. and Liu, J.S. (2013) Research on the Development Strategy of Film and Television Theme Park Based on Tourism Experience: A Case Study of Changying Century City. Geography Science, No. 11, 1362-1369.

[23] He, F.Y. (2015) Empirical Study on Tourist Identity of Environmental Education in Chengdu Giant Panda Breeding Base. Journal of Northwest Normal University, 51, 114-118.

[24] Wang, N. (2016) Research on the Impact of Tourism Corporate Social Responsibility on Tourists' Willingness to Buy: Based on Visitor Surveys in Nanjing and Shanghai. Consumer Economy, 32, 92-96.

[25] Wang, Y.M., Tao, C.J., Hu, J.J. and Cao, X.P. (2017) Research on the Safety Marking System of Cultural Heritage Scenic Spots Based on Tourist Identity: A Case Study of Qingcheng Mountain-Dujiangyan Scenic Spot. Regional Research and Development, 36, 78-82.

[26] Albayrak, T. and Caber, M. (2018) Examining the Relationship between Tourist Motivation and Satisfaction by Two Competing Methods. Tourism Management, 69, 201-213. https://doi.org/10.1016/j.tourman.2018.06.015

[27] Xu, Y.H., Li, W.L., Lin, C.H. and Lu, X.Y. (2015) An Empirical Study on the Relationship between Product Innovation, Visitor Satisfaction and Renewed Willingness in Theme Parks. Journal of Shanxi Agricultural University, 14, 1240-1244.

[28] Ilke, B. (2018) The Relationships between the Factors Affecting Perceived Service Quality, Satisfaction and Behavioral Intentions among Theme Park Visitors. Tourism and Hospitality Research, 18, 415-428. https://doi.org/10.1177/1467358416664566

[29] Xu, F.F. and Huang, L. (2018) Research on the Willingness to Use Smart Tourism System in Scenic Spots: Based on Integrated TAM and TTF Model. Tourism Journal, 3, 108-117. 


\section{Appendix I}

\section{Liuzhou OCT Visionland Questionnaire}

Dear sir/lady: Hello!

We are graduate students of Shenzhen Tourism College of Jinan University. Thank you very much for taking the time to fill out this questionnaire! The information you fill in will be for academic use only and will not be made public at all. Please choose the answer according to your true wishes and actual situation; thank you for your cooperation! We will keep you strictly confidential regarding personal privacy issues.

Please type " $\sqrt{ }$ " in the box of the item that you think is appropriate, or fill-in the text at the horizontal line.

I. Expectation and Satisfaction Evaluation Project

Do you think it is important? Are you satisfied with it?

\begin{tabular}{|c|c|c|c|c|c|c|c|c|c|c|}
\hline 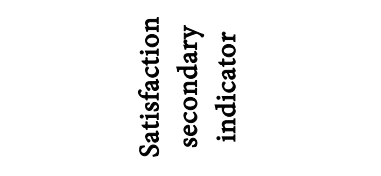 & 宫泀 & 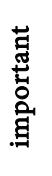 & 胥 & $\begin{array}{l}\text { 苐 } \\
\text { : } \\
\text { : } \\
\text { : }\end{array}$ & 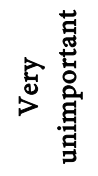 & 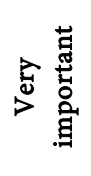 & 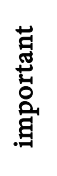 & 胥 & 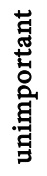 & 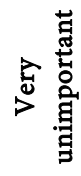 \\
\hline 1) Scenic network coverage & 1 & 2 & 3 & 4 & 5 & 1 & 2 & 3 & 4 & 5 \\
\hline 2) Smart ticket admission speed & 1 & 2 & 3 & 4 & 5 & 1 & 2 & 3 & 4 & 5 \\
\hline $\begin{array}{l}\text { 3) Tourism information is } \\
\text { released in a timely and } \\
\text { effective manner }\end{array}$ & 1 & 2 & 3 & 4 & 5 & 1 & 2 & 3 & 4 & 5 \\
\hline $\begin{array}{l}\text { 4) Humanization of vehicle } \\
\text { parking, etc. }\end{array}$ & 1 & 2 & 3 & 4 & 5 & 1 & 2 & 3 & 4 & 5 \\
\hline $\begin{array}{l}\text { 5) Scenic video surveillance } \\
\text { full coverage }\end{array}$ & 1 & 2 & 3 & 4 & 5 & 1 & 2 & 3 & 4 & 5 \\
\hline $\begin{array}{l}\text { 6) OCT Visionland APP } \\
\text { features functional convenience }\end{array}$ & 1 & 2 & 3 & 4 & 5 & 1 & 2 & 3 & 4 & 5 \\
\hline $\begin{array}{l}\text { 7) Scenic online consultation, } \\
\text { complaints, advice system }\end{array}$ & 1 & 2 & 3 & 4 & 5 & 1 & 2 & 3 & 4 & 5 \\
\hline $\begin{array}{l}\text { 8) Online payment } \\
\text { system fluency }\end{array}$ & 1 & 2 & 3 & 4 & 5 & 1 & 2 & 3 & 4 & 5 \\
\hline $\begin{array}{l}\text { 9) New technology } \\
\text { project experience }\end{array}$ & 1 & 2 & 3 & 4 & 5 & 1 & 2 & 3 & 4 & 5 \\
\hline $\begin{array}{l}\text { 10) New technology } \\
\text { project security }\end{array}$ & 1 & 2 & 3 & 4 & 5 & 1 & 2 & 3 & 4 & 5 \\
\hline $\begin{array}{l}\text { 11) Novelty of new } \\
\text { technology projects }\end{array}$ & 1 & 2 & 3 & 4 & 5 & 1 & 2 & 3 & 4 & 5 \\
\hline $\begin{array}{l}\text { 12) New technology projects } \\
\text { can be interactive }\end{array}$ & 1 & 2 & 3 & 4 & 5 & 1 & 2 & 3 & 4 & 5 \\
\hline 13) Number of items to visit & 1 & 2 & 3 & 4 & 5 & 1 & 2 & 3 & 4 & 5 \\
\hline $\begin{array}{l}\text { 14) Rationality of project } \\
\text { opening hours }\end{array}$ & 1 & 2 & 3 & 4 & 5 & 1 & 2 & 3 & 4 & 5 \\
\hline 15) Accessibility to the park & 1 & 2 & 3 & 4 & 5 & 1 & 2 & 3 & 4 & 5 \\
\hline
\end{tabular}




\section{Continued}

\begin{tabular}{|c|c|c|c|c|c|c|c|c|c|c|}
\hline $\begin{array}{l}\text { 16) The accuracy and } \\
\text { convenience of the guide map }\end{array}$ & 1 & 2 & 3 & 4 & 5 & 1 & 2 & 3 & 4 & 5 \\
\hline $\begin{array}{l}\text { 17) Rich recommendation } \\
\text { information on smartphones } \\
\text { and related software }\end{array}$ & 1 & 2 & 3 & 4 & 5 & 1 & 2 & 3 & 4 & 5 \\
\hline $\begin{array}{l}\text { 18) Promotion of scenic } \\
\text { spots such as websites, } \\
\text { WeChat, and scenic spots }\end{array}$ & 1 & 2 & 3 & 4 & 5 & 1 & 2 & 3 & 4 & 5 \\
\hline $\begin{array}{l}\text { 19) Mobile client to obtain } \\
\text { scenic road conditions, } \\
\text { routes, passenger flow }\end{array}$ & 1 & 2 & 3 & 4 & 5 & 1 & 2 & 3 & 4 & 5 \\
\hline $\begin{array}{l}\text { 20) Short message intelligence } \\
\text { smart provides travel } \\
\text { information }\end{array}$ & 1 & 2 & 3 & 4 & 5 & 1 & 2 & 3 & 4 & 5 \\
\hline $\begin{array}{l}\text { 21) Recommend this } \\
\text { park to others }\end{array}$ & 1 & 2 & 3 & 4 & 5 & 1 & 2 & 3 & 4 & 5 \\
\hline $\begin{array}{l}\text { 22) Overall evaluation } \\
\text { after the tour }\end{array}$ & 1 & 2 & 3 & 4 & 5 & 1 & 2 & 3 & 4 & 5 \\
\hline
\end{tabular}

\section{Appendix II}

1) Your gender: $\square$ male $\square$ female

2) Which of the following ways did you learn about the OCT Visionland theme park? (Multiple choice)

a) Media Advertisement b) Recommended by friends and relatives c) Internet d) Others

3) Do you know the OCT Visionland high-tech project?

a) I know very well b) I heard but didn't understand c) I have heard some d) Not at all

4) How long do you stay on the planet? a) Half day b) 1 day c) 2 days d) More than 2 days

5) What is the total cost of going to the planet?

a) Less than 200 b) $200-500$ c) $500-1000$ d) More than 1000

6) How many times have you come to the OCT Visionland theme park?

a) Once b) twice c) 3 times d) More than 3 times

7) What is your reason for your visit to the OCT Visionland? (Multiple choice)

a) Taking a photo punch and sending a circle of friends b) Picking up and experiencing high-tech projects c) Relaxing d) Experiencing different landscape culture

8) Which theme parks have you been to?

a) Domestic theme parks, Happy Valley, Chimelong, Fangte, etc. b) Foreign theme parks, Disney, Universal Studios, etc. c) Have never been to anywhere d) Have been to both domestic and foreign theme parks.

9) Age: $\square 19$ - 28 years old $\square 29$ - 45 years old $\square 46$ - 64 years old $\square 65$ years old or older

10) You are from: $\square$ Liuzhou $\square$ Guangxi Autonomous Region $\square$ Provincial Foreign Country $\square$ Foreign 
11) Education level: $\square$ High school and below $\square$ High school/specialist $\square$ Undergraduate and above

12) Occupation: $\square$ Civil servants $\square$ Company employees $\square$ Business owners $\square$ Farmers $\square$ Students $\square$ Retirees $\square$ Military $\square$ Others

13) Annual household income (Ten thousand yuan): $\square 1-3 \square 3-8 \square 8-15 \square$ $15-30 \square 30$ or more

14) Have you reviewed the information before visiting the OCT Visionland? a) Yes b) No

15) Before the tour, in the process of obtaining the information of the OCT Visionland, you think

a) Can't find the information you need, b) a lot of information are very scattered and the screening is troublesome, c) a lot of information, which needs to be filtered according to your own requirements, d) some information does not match the actual situation of the scenic spot, e) others

16) In order to successfully visit the scenic spot, please select the travel information that you think is most important (multiple choice)

a) Scenic introduction information, b) scenic traffic service information, c) charge items, d) basic service information (toilet, etc.), e) supporting service information (shopping, dining), f) security message, $g$ ) others

17) What are your thoughts or suggestions for the planet? Welcome to share with us. 